\title{
エルゴディック磁気リミタ配位における トカマク周辺部の磁界構造解析
}

\author{
准 員玉越 富夫 (名古屋大) \\ 准 員三宅正之(名古屋大) \\ 正員山田裕之 (中部電力)
}

\author{
正 員 高村 秀一(名古屋大) \\ 正 員 奥 田 孝 美 (名古屋大)
}

\section{1.はじめに}

エルゴディック磁気りミタ (EML) はトカマクに㧍 ける不純物，プラズマ粒子および熱の制御のための新 しい方法上して注目されている(1)ー(3)。プラズマ電流 に上る磁力線のひ放りに共鳴するへリカル磁界を外部 加加え，共鳴層において磁力線のつなぎ替えによ～ て磁気島をつくる。トーラス効果によって生じた，周 辺部におりる一連の磁気島の重なりによって磁力線の 統壾的な乱れをつくり，磁気面を破壊する。周辺部の ある厚さの領域を磁力線力乱雑汇通り拔けるので，こ れはエルゴディック層と呼ばれることが多い。磁力線 に沿って壁またはリミタへの粒子輸送が増大するため に，そこでのプラズマ粒子のリサイクリングが増し， 中性化, 電離, 荷電交換が頻繁に発生し, 壁付近のプ ラズマが高密度, 低温度化し：その結果プラズマと壁 との相互作用が緌和される。また，スパッタリングに よってリミタや壁で発生した不純物が，プラズマコア 部に流入するのを阻止する遮へい效果をす有する。通 常のポロイダルダイバータに比較して構造が簡単であ り，コイル電流も格段に小さい点からも魅力的であ る。一方，最近，プラズマ周迅部の特性がコアプラズ マの閉じ込めを根本的に変えるととが認識され始めて いる。周边プラズマの制御手段としても EMLは重要 な位置つけにある。

Numerical Analysis on Magnetic Field Structure of Ergodic Magnetic Limiter in a Tokamak Periphery. By Tomio Tamakoshi, Associate, Masayuki Miyake, Associate (Faculty of Engineering, Nagoya University), Hiroyuki Yamada, Member (The Chubu Electric Power Co. Inc.), Shuichi Takamura, Member \& Takayoshi Oktuda, Member (Faculty of Engineering, Nagoya University).

玉越富夫：准員, 名古屋大学工学部電気工学科

三宅正之：准員, 名古屋大学工学部電気工学科

山田裕之：正虽，中部能力(株)

高村秀一：正員, 名古屋大学工学部電気工学科

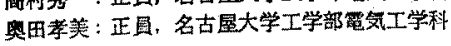

EML に関する TEXT トカマクにおける実駼は， プラズマ端における電子温度の低下に基つくと考えら れる金属不純物の減少を示し，その有望性が実証され $た^{(4)}$ 。

しかしながら，プラズマ端におけるプラズマパラ メータが著しく非対称になっているととがわかってき た。例えば，プローブへのイオン飽和電流はポロダイ ル力向に沿って大きく変化し，空間的変調を受けてい ることが, TEXT の実験のみならず，著者らの実験に よっても明らかにされている(5)(6)。TEXTトカマクに おける周辺部のプラズマ冷却も，プラズマ表面にわ たって一様に生じているのではなく，空間構造をすっ ていると予想される。これらの現象を系統的に理解す るには，その基礎となる磁力線の構造を正確に，かつ 䛨細隹調べるとが必須である(7)。EMLの実験にお いては，プラズマの密度，温度のみならず電位をむ大 きく変化させる。また逆に, 電界が粒子の輸送へ跳返 る。との場合，EML の印加によって軸対称性を破る ため，電子の非両極性輪送が重要である。これには磁 力線の壁へのつながり方, 例えば接続長や磁気島ので き方，統計性の度合が大きな影響を及ぼす。

更に次の点を指摘したい。EMLの磁界配位は環状 ヘリカル系と多くの共通点を有する。最外款磁気面の 近傍およびその外側の磁力線の構造が, EML のそれ 々極めて類似的である。このエルゴディック首での粒 子や熱の輪送は，周辺部のプラズマの閉じ込めにとっ て重要であるばかりでなく，へリカルダイバータが成 立するかどうかを決定するうえです十分詳細な磁界計 算が要請されている。

本論文では，上述のような背景の下で，EMLスキー ムにおける磁界の空間的構造などを研究するための計 算手法について述へると共に, 磁界構造の特性につい て議諭する。局所へリカルコイルによって摂動を受け たトカマク周辺部の磁界構造に関しては, Feneberg 
ら (8)が初步的な解析を行ったのに始まる。Martinら は，写像方程式を用いて磁力線のトポロジ一を系統的 に調べた。しかし，彼らは局所へリカルコイル形状を 著しく簡略化して計算を行ったので，実際の害験との 対応に関しては信頼性がそしかった。すなわち，図1 に示す局所へリカルコイルのトーラス方向電流素片は 無限に長いとし，ポロイダル方向電流素片は無視する といっだ近似である。同様の手法が TEXT トカマク の場合にあ適用された ${ }^{(10)}$ 。

本研究において，著者らはビオ・サバール方程式を 用いて局所ヘリカルコイルの構造を正確に取入れた計 算機コードを開発した。すなうち，トーラス方向のコ イルの有限性を考虑し，ポロイダル方向のわたり導体 の寄与も取入れた。トカマク平衡に関しては，同軸円 筒磁気面をまず仮定した。これにより，磁力線の構造 がかなり正確に記述でき，磁力線の壁へのつながり方 や，壁付近での磁界の構造性が明らかにされ，また磁 力線の拡散過程も詳細に検討することができる。プラ ズマ電流による磁界のひねりと外部へリカル磁界のそ れとの共鳴性についてあ興味ある結果が得られる。

更に進んで，トカマク平衡磁界にシャフラノフの平 衡解析解を用いるととによって, 磁気面の水平方向の シフトが取入れられ，磁気島の位置など，より正確に 知ることができる(11)。本論文においては，これまで 不十分であったてれらの新しい観点について議論す る。

\section{2. 局所ヘリカルコイルの構造と生成 される磁界}

$\langle 2 \cdot 1\rangle$ 局所へリカルコイルの位置とその構造 著者らによって，EMLに関する研究が現在 HYBTOK-IIトカマク装置 (大半径 $R_{0}=40 \mathrm{~cm}$, 小半径 $b=13 \mathrm{~cm}$, リ夕半径 $a=11 \mathrm{~cm})$ を用 いて行われているので, この装置のパラメータ を用いて以下, 数值計算を行う。以下の結果は HYBTOK-II 飞特有ではなく, 円形断面卜カマ クに等しく適用できるてとを注意したい。図 1 は 1 個の局所へリカルコイルの構造を示している。 コイルのポロイダルモードを $m$ とすると、へリ カ儿磁界強度は $r^{m-1}$ に比例するので, 周辺部のみ ヘリカル磁界の摄動を受け、コア部への影響は十 分小さい。図 2 の斜線で示されるように，てのよ うなコイルがトーラスに沿って8 個設置される。 各コイルのトーラス方向電流素片 (水平部導体) のポロイダル位置とバーの長さが図 3 亿示され る。各コイルに通電する電流の向きは, 図 4 汇ま
とめられている。励起するモードによって通電パター ンが異なるのであるが,コイル配置としては $m / n=6 / 2$ モードを効率良く励起するよう設計されているので， $m / n=6 / 1$ モードの場合は後述するように $m / n=-6 / 1$ モードの成分む多分に励起するなどして，モードの純 粋さが悪い。ここで, $n$ はトロイダルモード数を示す。

〈2・2〉局所ヘリカルコイルによって生成される磁 界 ㄷこで採用される座標系を図 5 に示す。デカル 卜座標 $(X, Y, Z)$, 円筒座標 $(R, \phi, Z)$ ，そしてトーラス 座標 $(r, \theta, \phi)$ 系が用いられる。i 番目のヘリカルコイ の水平部導体の端点の座標は

$$
\begin{aligned}
& \left.\begin{array}{l}
X_{i}{ }^{h}=r_{h} \cos \beta_{i} \\
Y_{i}{ }^{h}= \pm\left(R_{0}+X_{i}{ }^{h}\right) \tan 12^{\circ} \\
Z_{i}{ }^{h}=r_{h} \sin \beta_{i}
\end{array}\right\} \\
& \beta_{i}=(i-1) 30^{\circ}+\theta_{1} \\
& \theta_{1}=\left\{\begin{array}{l}
+7.5^{\circ} \text { for } \S 1,5,9 \text { and } 13 \\
-7.5^{\circ} \text { for } \S 3,7,11 \text { and } 15
\end{array}\right.
\end{aligned}
$$

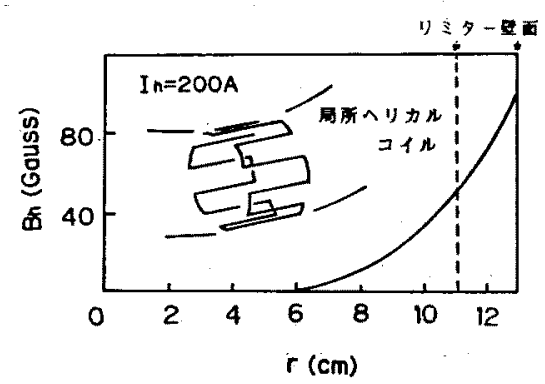

図 1 局所へリカルコイルの構造および ヘリカル磁界強度の径方向分布

Fig. 1. Structure of local helical coil and radial profile of helical field intensity.

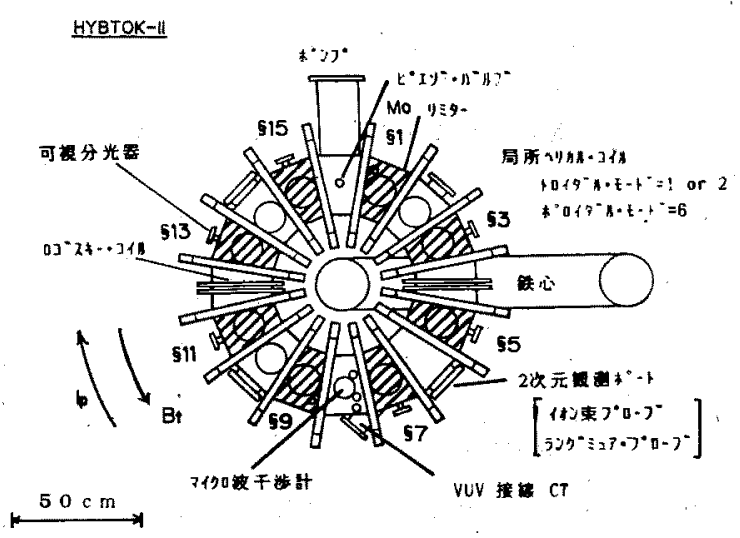

図 2 HYBTOK-IIトカマク装置の平面図

Fig. 2. Top view of HYBTOK-II tokamak machine. 

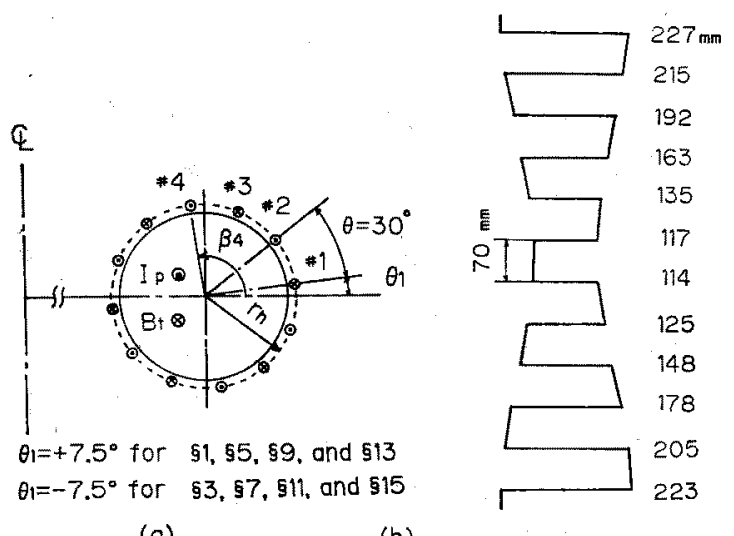

(a)

(b) $\quad l=2(r n \cos \theta+R o) \tan 12^{\circ}$

図 3 トロイダルコイル電流素片のポロイダル 位置 (a)と局所へリカルコイルの展開図 (b)

Fig. 3. Poloidal position of toroidal current bar (a) and expanded diagram of local helical coil (b).

$$
\text { [a] }
$$

$$
\text { [b] }
$$

困 4 局所ヘリカルコイルに流れる電流の

$$
\text { 向きとモードの関係 }
$$

Fig. 4. Current flow diagram for (a) $\mathrm{m} / \mathrm{n}$ $=6 / 1$ and (b.) $m / n=6 / 2$.

となる。ここで, $r_{h}$ は図了で示されているように、コ イル導体の巻かれている小半径である。

ヘリカルコイルの渡り部については， $X-Z$ 平面内 にあると近似して, $X_{i}^{w}=X_{i}^{h}, Y_{i}^{w}=\left(Y_{i}^{h}+Y_{i+1}{ }^{h}\right) / 2$, $Z_{i}{ }^{w}=Z_{i}{ }^{h}$ となる。以下, 添字 $i$ 妙省略するととにす る。

点 $(x, y, z)$ 加, ヘリカルコイル水平部導体の端点 までの距離は， $d_{1(2)^{h}}=\left\{\left(X^{h}-x\right)^{2}+\left( \pm Y^{h}-y\right)^{2}+\left(Z^{h}\right.\right.$ $\left.-z)^{2}\right\}^{1 / 2}$ となり, 端点見込む角度は,

$$
\cos \alpha_{1(2)^{h}}=\frac{\left(l^{h}\right)^{2} \pm\left\{\left(d_{1}^{h}\right)^{2}-\left(d_{2}^{h}\right)^{2}\right\}}{2 l^{h} d_{1(2)^{h}}}
$$

となり,ヘリカルコイルの水平部導体までの垂線の長 さは $d_{0}^{h}=d_{1}^{h} \sin \alpha_{1}^{h}=\left\{\left(X^{h}-x\right)^{2}+\left(Z^{h}-z\right)^{2}\right\}^{1 / 2}$ とな
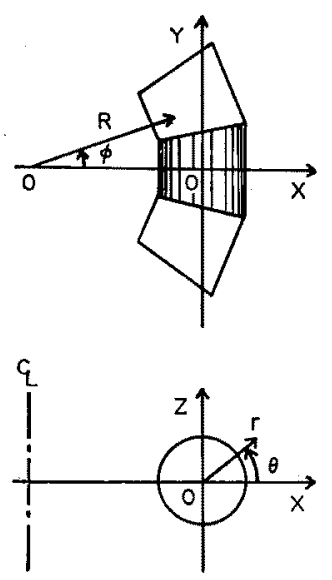

図 5 座標系

Fig. 5. Coordinate system.
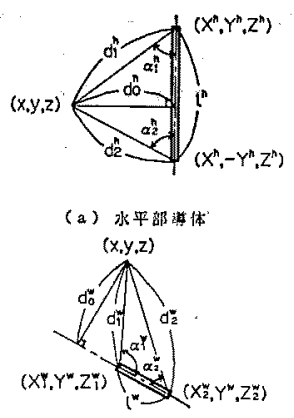

(b) 渡鸟部体

図 $6 d$ および $\alpha$ の定義

Fig. 6. Definitions of $d$ and $\alpha$.

る。以上の諸量については図6（a）に図示されてい る。ヘリカルコイルの渡り部導体についても同様に $d_{1(2)^{w}}=\left\{\left(X_{1(2)^{w}}-x\right)^{2}+\left(Y^{w}-y\right)^{2}+\left(Z_{1(2)^{w}}-z\right)^{2}\right\}^{1 / 2}$ と なり，端点を見込む角度は

$$
\cos \alpha_{1(2)^{w}}=\frac{\left(l^{w}\right)^{2} \pm\left\{\left(d_{1}{ }^{w}\right)^{2}-\left(d_{2}{ }^{w}\right)^{2}\right\}}{2 l^{w} d_{1(2)^{w}}} .
$$

である。渡り部導体への垂線の長さは $d_{0}{ }^{w}=d_{1}{ }^{w} \sin \alpha_{1}{ }^{w}$ となる。以上の諸量については(b)図に図示されてい る。

ヘリカル磁界の $(X, Y, Z)$ 成分への, 水平部導体の 寄与は図 7(a)を参照して,

$$
B X^{h}=-B^{h} \sin \gamma, \quad B_{Y}^{h}=0, \quad B z^{h}=B^{h} \cos \gamma
$$

ことで,

$$
\sin \gamma=\left(Z^{h}-z\right) / d_{0}{ }^{h}, \quad \cos \gamma=\left(X^{h}-x\right) / d_{0}{ }^{h}
$$

である。渡り部導体の寄与は (b)図を参照して, 


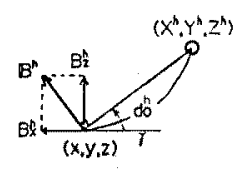

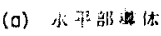

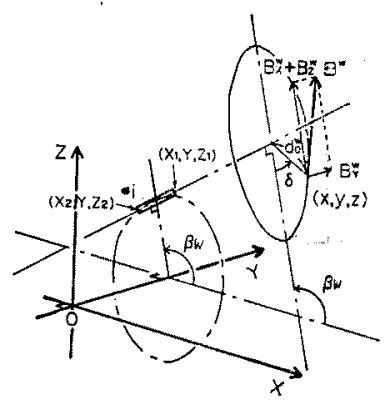

(b) 诚り邵站

図 7 水平部電流素片および渡り部電流素片 に流れる電流によって生成される磁界

Fig. 7. Magnetic field produced by horizontal or poloidal current bar.

$$
\left.\begin{array}{l}
B_{X}{ }^{w}=B^{w} \sin \delta \cos \beta^{\prime} \\
B_{Y}{ }^{w}=B^{w} \cos \delta \\
B z^{w}=B^{w} \sin \delta \sin \beta^{\prime}
\end{array}\right\}
$$

となる。とこで，ヘリカル磁界の絶対值 $B^{n}, B^{w}$ は， ヘリカル電流が $I_{h}$ のとき

$$
\begin{aligned}
B^{h(w)}= & \frac{\mu_{0} I_{h}}{4 \pi d_{0}^{h(w)}}\left(\cos \alpha_{1}^{h(w)}+\cos \alpha_{2}^{h(w)}\right) \\
= & \frac{\mu_{0} I_{h}\left(d_{1}^{h(w)}+d_{2}{ }^{h(w)}\right)}{8 \pi l^{h(w)} d_{0}^{h(w)} d_{1}^{h(w)} d_{2}{ }^{h(w)}} \\
& \times\left\{\left(l^{h(w)}\right)^{2}-\left(d_{1}^{h(w)}-d_{2}^{h(w)}\right)^{2}\right\}
\end{aligned}
$$

で与えられる。

最後に, トーラス座標湾換して $\left(B_{r}, B_{\theta}, B_{\phi}\right)$ を得 る。ただし， $B_{\phi}$ は閉し込め用トロイダル磁界に比較 して十分小さいので, 磁力線の追跡計算では無視し た。

トーラスが合同な八つのセクション（各1個の局所 ヘリカルコイルが巻いてある) に分りられるので，そ の一つについて磁界が計算されればよい。すなわち,

因 5 に示されるように，局所ヘリカルコイルの中心を 原点として $-\pi / 8 \leqq \phi \leqq \pi / 8$ の部分についてヘリカル 磁界を計算して磁力線の追跡を行い，乙の計算を 8 回 繰返すととでトーラス1周にわたるへリカル磁界の值 を計算した。 $\phi \approx \pm \pi / 8$ ではへリカル磁界強度は十分 小さいので，考えているセクション以外の局所コイル 電流の作る磁界は無視した。

$\xi 1,5,9,13$ セクションに巻かれているコイルを $A$ コイル， $\xi 3,7,11,15$ 七クションに巻功ているコイ ルを $B$ コイルと呼ふ。これら二組の局所へリカルコ イルは $X$ 軸について軸対称であるので, $A$ コイルの みについてへリカル磁界を計算すれば $B$ コイルから の磁界を改めて計算せずとも求められる。更に，へリ カルコイルの水平部導体は $X Z$ 面について面対称で あるので，例えば $Y<0$ の領域だけを計算すれば, $Y>0$ の領域の值も求められる。結局，座標の絶対值 $(|x|,|y|,|z|)$ 加同じ場合，表1のような関係があ る。水平部導体加らの寄与は領域 I とII, 渡り部導体 加らの寄与は領域 I, II, III, N の磁界を計算すれば十 分である。これらは表 1 に波線で示されてある。

以上の上うに, 局所ヘリカルコイルの作り出す磁界 を，ビオ・サバール則を使って忠実に計算するのであ るが，磁力線追跡の各ステップごとにへリカル磁界計 算を行うと膨大な計算時間が必要となり，スーパーコ ンピュータをあってしてもあまり現実的ではない。従

表 1 ヘリカル磁界コイルの対称性

Table 1. Symmetry of magnetic field generated by local helical coils.

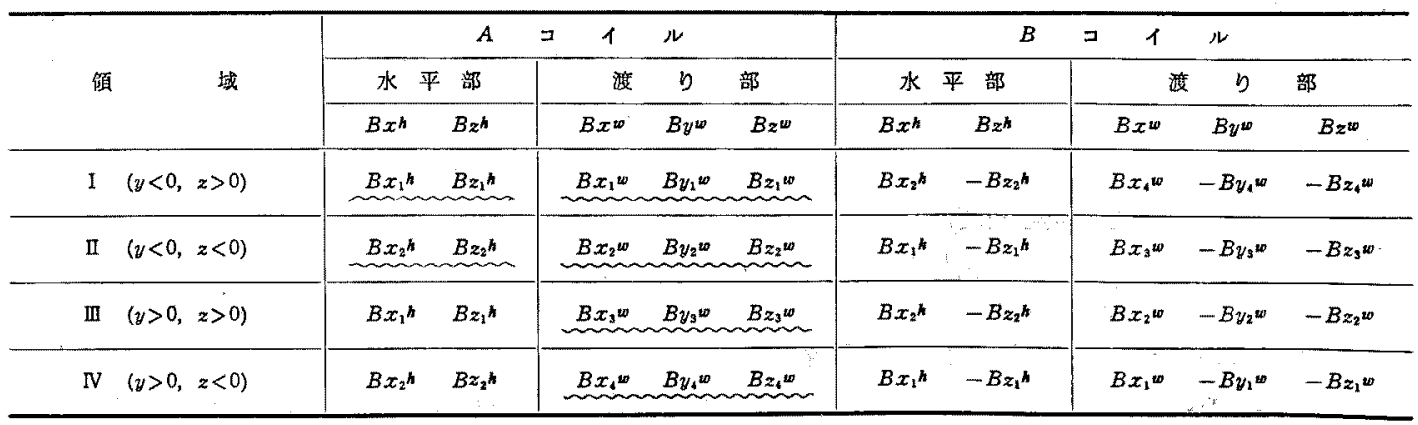


って，トーラスの中をメッシュに切って各格子点のへ リカル磁界をあらかじめ求めておき，任意の点のへリ カル磁界はその点の周围 4 格子点におけるへリカル磁 界から内括計算して求めた。すなわち, 格子点 $(l, m)$, $(l+1, m),(l+1, m+1),(l, m+1)$ で囲まれる任意の点 $\left(r_{i} \leqq r \leqq r_{l+1}, \theta_{m} \leqq \theta \leqq \theta_{m+1}, \phi=\phi_{n}\right)$ におけるへリカル磁 界を次式加ら内插した。

$$
\begin{aligned}
B_{\boldsymbol{r}(\theta)} & (r, \theta, \phi) \\
= & (1-s)(1-t) B_{r(\theta)}\left(r_{l}, \theta_{m}, \phi_{n}\right) \\
& +s(1-t) B_{r(\theta)}\left(r_{l+1}, \theta_{m}, \phi_{n}\right) \\
& +(1-s) t B_{r(\theta)}\left(r_{l}, \theta_{m+1}, \phi_{n}\right) \\
& +s t B_{r(\theta)}\left(r_{l+1}, \theta_{m+1}, \phi_{n}\right) \ldots .
\end{aligned}
$$

ここで， $0 \leqq(s, t) \leqq 1$ を満足する $s ， t$ はそれぞれ $r, \theta$ の内分比である。

\section{3. トカマク平衡磁界と磁力線の式}

〈3.1〉同心円上磁気面（モデル 1) トロイダル 磁界は $B_{\phi}=\left(R_{0} / R\right) B_{\phi 0}$ によって与えられる。平衡の ためのポロイダル磁界は，次に示すように同心円上磁 気面を想定するのが最も簡単化した形である。トーラ 又効果は $B_{\theta}=\left(R_{0} / R\right) B_{\theta 0}$ によって取入れる。

$a$ をリミタ半径とすると, $r<a$ に対して $B_{0}$ は

$$
B_{\theta_{0}}=\frac{\mu_{0}}{2 \pi r} \int_{0}^{r} 2 \pi r j(r) d r
$$

で与えられる。とこで，電流密度として放物線分布を 板定する。

$$
j(r)=\frac{2 I_{p}}{\pi a^{2}}\left\{1-\left(\frac{r}{a}\right)^{2}\right\}
$$

$r \geqq a$ の領域にはプラズマ電流が流れないとして,

$$
B_{\theta 0}=\mu_{0} I_{p} / 2 \pi r
$$

である。このもデルは磁力線が乱雑化してゆく様子や 磁力線の拡散過程を調べるには都合が良く, 極めて有 用である。しかし，ポロイダル面上における磁気島の 位置を，このコードによって正確に知ることができな い。なぜなら，プラズマ圧力効果に基つく磁気面の シャフラノフシフトが考虑されていないからである。

\section{〈3・2〉 シャフラノフの平衡解析解（モテル 2)}

周辺部汇外部へリカル磁界が加えられ，平衡が崩さ れるので，笽密にはトカマク平衡解は使えない。しか し, 周辺部に怙けるポロイダル磁界は, 摄動の小さい 内部のプラズマ電流の寄与の皘分された結果であるの

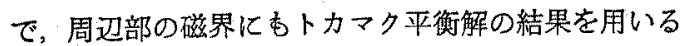
近似は許されるであろう。

シャフラノフによって与えられた磁束関数は次式の ように堚かれる(12)。

$$
\begin{aligned}
\Psi= & \frac{\mu_{0} I_{p} R_{0}}{2 \pi}\left(\ln \frac{8 R_{0}}{r}-2\right) \\
& -\frac{\mu_{0} I_{p}}{4 \pi}\left\{\ln \frac{r}{a}+\left(\Lambda+\frac{1}{2}\right)\left(1-\frac{a^{2}}{r^{2}}\right)\right\} \\
& \times r \cos \theta \ldots \ldots \ldots \ldots \ldots \ldots \ldots \ldots \ldots \ldots \ldots \ldots \ldots \ldots
\end{aligned}
$$

ここで， $\Lambda$ はポロイダルベータ $\beta_{P}$ とプラズマ柱の内 部インダクタンス $l_{i}$ を用いて $\Lambda=\beta_{p}+\left(l_{i} / 2\right)-1$ で与 えられる。磁束関数を使う之, 平衡磁界の径方向成分 とポロイダル方向成分は次式で決められる。

$$
R B_{r}=-\partial \Psi / r \partial \theta, R B_{\theta}=\partial \Psi / \partial r .
$$

すなわち。

$$
B_{r}=-\frac{\mu_{0} I_{p}}{4 \pi R_{0}}\left\{\ln \frac{r}{a}+\left(\Lambda+\frac{1}{2}\right)\left(1-\frac{a^{2}}{r^{2}}\right)\right\} \sin \theta
$$

$$
\begin{aligned}
B_{\theta}=- & \frac{\mu_{0} I_{p}}{2 \pi r}-\frac{\mu_{0} I_{p}}{4 \pi R_{0}}\left\{\ln \frac{r}{a}-1\right. \\
& \left.+\left(\Lambda+\frac{1}{2}\right)\left(1-\frac{a^{2}}{r^{2}}\right)\right\} \cos \theta
\end{aligned}
$$

この定式化の下では, 容器中心からの磁気面中心のず れ、いわゆるシャフラノフシフトは次式で与えられ る。

$$
\Delta(r)=-\frac{r^{2}}{2 R_{0}}\left\{\ln \frac{r}{a}+\left(\Lambda+\frac{1}{2}\right)\left(1-\frac{a^{2}}{r^{2}}\right)\right\}
$$

当然, $\Delta(a)=0$,であり, 磁気軸のシフト量は $\Delta(0)$ $=\left(a^{2} / 2 R_{0}\right)(\Lambda+1 / 2)$ で与えられる。

〈3.3〉磁力線の方程式 磁力線を表す微分方 程式は

$$
d r / d \phi=R B_{r} / B_{\phi}, \quad d \theta / d \phi=R B_{\theta} / r B_{\phi}
$$

で表される。(11)式で得られたへリカル磁界を(17), (18)式のトカマク平衡磁界掞よびトロイダル磁界に加 え，上記磁力線の方程式をルンゲ・クッタ法を用い て，トーラス方向に磁力線を追跡する形で解いた。

\section{4. 計算結果}

〈4.1〉モテル1の結果 トーラス方向に周回し ながら磁力線をたどってゆくときあるポロイダル断 面を磁力線が貫通する点をプロットしたのが図8であ る。ポロイダル断面としては，実験においてラングミ ニアプローブなどで二次元的にプラズマパラメータの 変化などを測定する，図2で示される二次元観測ポー トを選んだ。磁力線の追跡方向は, 同図で右回りであ る。以下，すべての場合に括いてトロイダル磁界 $B_{t}$ 


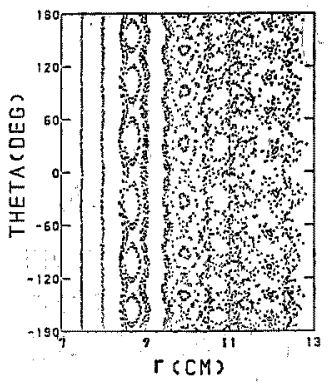

(a) $\ln =100 \mathrm{~A}$

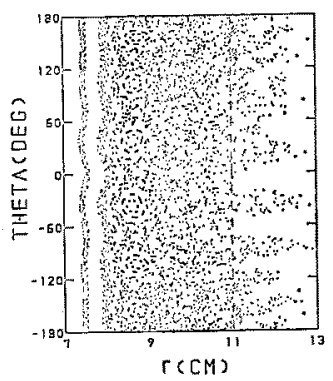

(c) $\operatorname{In}=600 \mathrm{~A}$

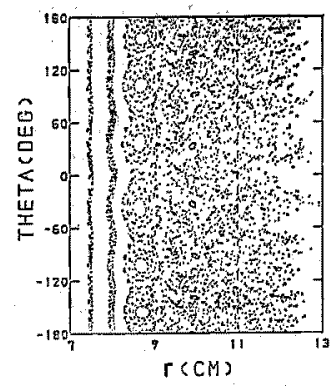

(b) $\operatorname{In}=300 \mathrm{~A}$

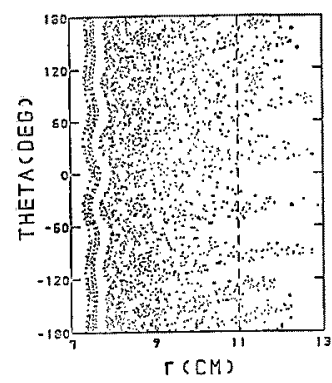

(d) $\operatorname{In}=1000 \mathrm{~A}$
ポロイダル角に対して展開した形でされている。 $I_{p}=-15 \mathrm{kA}(\mathrm{CW}), B_{t}=0.4 \mathrm{~T}$

図 8 プラズマ電流によるポロイダル磁界と外部 ヘリカル磁界のひねりが共鳴する場合の $m / n=$ 6/2 モードに対する磁力線の貫通パターン

Fig 8. Puncture plots of magnetic field lines for $m / n=6 / 2$ when the rotation of poloidal field due to plasma current has the same direction as that of helical field due to local helical coil.

は $0.4 \mathrm{~T}$, リミタ半径 $a$ は $11 \mathrm{~cm}$ とした。磁力線は 小半径 $r=7.5 \sim 12.5 \mathrm{~cm}$ まで $5 \mathrm{~mm}$ ごとに(11 本), 各 $r$ についてポロイダル角 $\theta=0 \sim 324^{\circ}$ まで $36^{\circ}$ ごと に(10 本), 各点から出発させ, トーラスに治って 100 回周回させた。磁力線がトーラスを 100 周する前に真 空容器壁に衙突した場合は，そこで計算を打切った。 図8は $I_{p}=-15 \mathrm{kA}$ で, ヘリカルコイルのモードは $m / n=6 / 2$ の場合である。プラズマ電流住よる磁力線 のひねりと、ヘリカル磁界のひねりが共鴊し，へリカ ルコイル電流の最す小さい(a)図からわかるように， $r=8.5 \mathrm{~cm} k m=6$ の主モード磁気島があり, トーラ 不効果で生み出された $m=7,8,9$ そして 10 の側帯 波モードの磁気島加 $r=10.0,10.7,11.5$ そして 12.0 $\mathrm{cm}$ にそれぞれ勧測される。これらの点で安全係数 9 はそれぞれ 3.5，4，4.5，そして5になっている。(b) 〜 (d) 眓のように, 順次へリカルコイル電流を大きく
してゆくと，壁に近い高次の磁気島が相互に重なり合 い統計化してゆくのが観測される。一方，コイル電流 が大きい場合に, 容器壁付近で点がない領域之密集し ている領域とが，くさび状になって交互に現れている のがわかる。点のない領域から出発した磁力線はすぐ に壁に行ってしまう。つまり，壁への接続長が短いて とを意味している。いまの場合，6個のへリカル導体 による磁気リミタ構造になっているのがわかる。ての ように，壁からある距離離れた領域では磁気島の重な りで磁力線がカオス化してゆくと同時に，壁近傍では 上述のような構造性が現れることに注意しなければな らない。

さて，プラズマ電流の向きを逆転すると，ヘリカル 磁界のひねりの向きと，プラズマ電流による磁界のひ ねりの向きが反対になり，共鳴が得られない。このよ うな場合に相当する磁力線の貫通パターンを図 9 に示 す。壁化近い磁気面でも，わずかに波うちが見られる 程度の摄動を受けているにすぎい。このように， HYBTOK-II の局所へリカルコイルはトーラスに沿 って対称性良く配置され， $m / n=6 / 2$ を効率良く生成 し，他の寄生モード生成が少ないととが理解される。

四 4 亿示したように，元来 $m / n=6 / 2$ モードを励起 するように配置された局所へリカルコイルの電流の向 きを調整することにより， $m / n=6 / 1$ モードを作り出 すととあ可能である。安全係数を 6 近くに選ぶため, プラズマ電流は図8 の場合のほほ半分に選ふ。 $m / n=$ 6/2 の場合と異なり，プラズマ電流の向きを逆にして, 主モードに対する非共鳴状態をつくってあ，ててでは

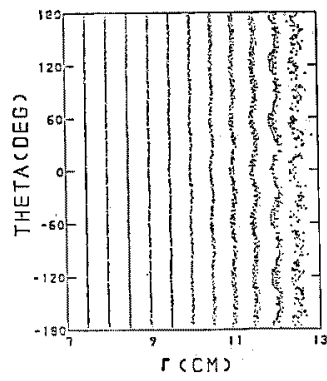

(a) I $n=300 \mathrm{~A}$

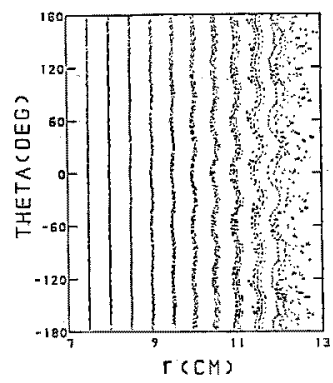

(b) I $n=600 A$

$$
I_{p}=+15 \mathrm{kA}(\mathrm{CCW}), B_{t}=0.4 \mathrm{~T}
$$

図 9 プラズマ電流によるポロイダル磁界と外部 ヘリカル磁界のひ㸚りが非共鳴の場合の $m / n=$ 6/2 モードに対する磁力線の貫通パターン

Fig. 9. Puncture plots of magnetic field lines for $m / n=6 / 2$ when the rotation of poloidal field due to plasma current has the opposit direction to that of helical field due to local helical coil. 
示されないが，磁気面の破壊がかなり見られる。すな わち，生成されるモードの純䊉さにそしいといえる。

さて，以上のような複雑な磁界構造を定量的纪表現 するにはいかにしたらよいであるうか。カオスの研究 分野では，リヤプノフ指数老用いてその乱隺さの度合 を表現する指標にしている。一方，とのような統計性 磁気面の場合に; 磁力線の拡散係数を求如プラズマ 粒子はこの磁力線に沿って動くとして，粒子の径方向 の拡散係数安磁力線の搪散係数から求好々いう手法 がてれまで用いられてきている(13)(14)。しかし，著者 らは原点任立ち民杘って，乙のような磁力線の振舞いが 搪散係数という算純な形で記述できるのかどうかとい う点加ら考察するために，ある場所加ら出発した磁力 線がどのように広がってゅくかを調べた。図 10 にお いて，横軸はトーラス周回数であり，磁力線に沿った 長さに比例する。緃軸は出発点の半径加らの径方向の ずれの2乗を，同一半径上喠々のポロイダル位置から 出発した磁力繶にわたって平均した值，すなわち磁力 線の広がり具合を示したグラフである。グラフの曲楾 の傾きが 1 である場合，すなわち変位の 2 乗平均が磁 力線に沿った追跡距離に比例するならば，磁力線が挔 散的に広がっており，拡散係数で記述するのが妥当で あるといえる。しかし，同図に示されるように必ずし あそうではなく，傾きはすう少し大きい場合が多いよ うである。これは，磁力線の相関が磁力線に沿った長 さ (時間) に対して, 指数関数的に減裹せずにべき乗 で瑊衰するために，長時間相関が現れることと関係し

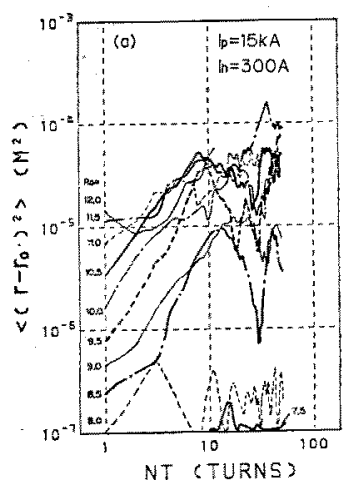

(a) $m / n=6 / 2$

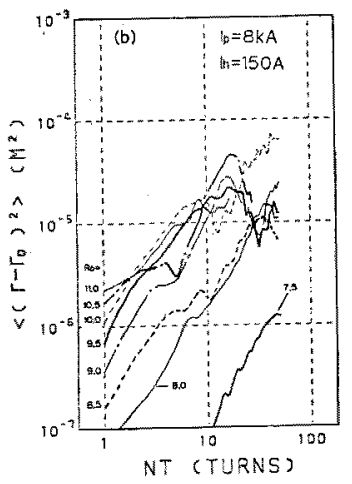

(b) $m / n=6 / 1$
パラメータは初期位跙，10 個心睪なったポロイダル

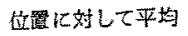

図 10 トーラス周回数に対する磁力線の 经方向移動距離 22 莱

Fig. 10. Magnetic diffusion process shown by radial excursion squared of field lines with respect to the toroidal turn taking the start position as a parameter.

電学論 A, 108 卷 12 号, 昭 63
ているようである(15)。すなわち，磁力線の動きはフ ラクタルになっているととを想像させる(16)。しかし, この興昧樑い点については別途詳細に检討する必要が ある。

〈4・2〉モデル2の結果：モデル2ではトカマ ク平衡に関する解析解を用いているので,シャフラ ノフシフトが考虑されることになる。図11（a） HYBTOK-II の場合の磁気面の例を示す。実験条件 に合せて $A=-0.74$ とした。リミタ半径は $a=11 \mathrm{~cm}$ であり，トロイダル磁界は $B_{t}=0.4 \mathrm{~T}$ である。リミ 夕内側の磁気面がトーラス対称軸比関して外側方向に シフトしているのがかかる。局所へリカルコイルのモ 一ド数 $m / n=6 / 2$ の場合の磁力線の貫通パターンを (b)〜 (d)図に示す。例えば，因8 (a) と図 11(b)あ るいは図8(b)と図11(c)を比較す百ことにより， 磁気島の形や位置が異なっているのが見てとれる。実 験結果の考察には，実験で求められた $\Lambda$ の值に応じ てモデル2で計算した結果を使うのが最む妥当である と考えられる。

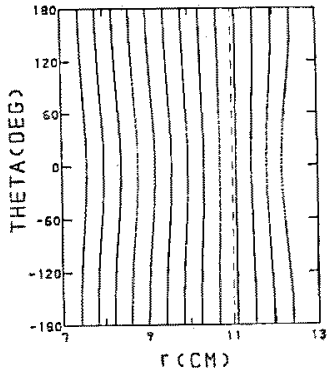

(a) $\mid n=O A$

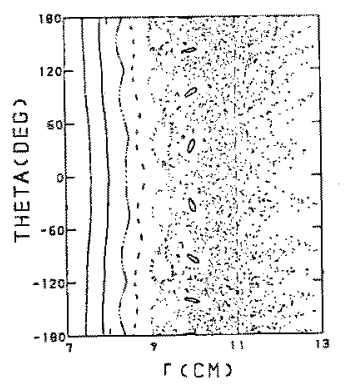

(c) $1 \mathrm{n}=300 \mathrm{~A}$

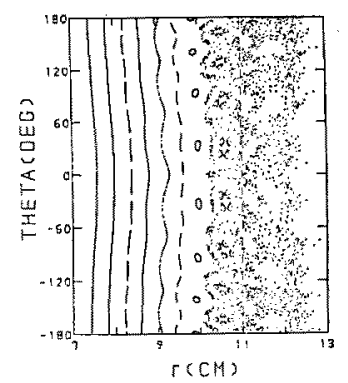

(b) $1 n=100 \mathrm{~A}$

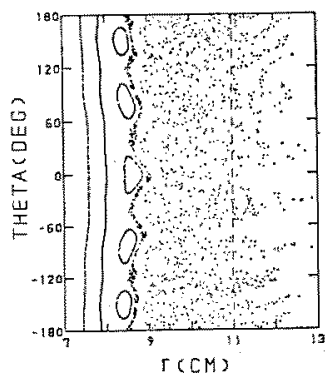

(d) $\ln =600 \mathrm{~A}$

$$
I_{b}=15 \mathrm{kA}, B_{t}=0.4 \mathrm{~T}
$$

目 11 シャフラノフ平衡解に基つく $m / n=$ 6/2 モードに対する磁力線の貫通パターン

Fig. 11. Puncture plot of magnetic field lines for $m / n=6 / 2$, taking into account of Shafranov equilibrium shift. 


\section{5. 終りに}

局所ヘリカルコイルの形状をできる限り正確に取入 れて，それの作り出すへリカル磁界を計算し，磁力線 を追跡する計算機コードの開発を行った。トカマク平 衡磁界に関しては同心円状磁気面を仮定する簡単な扱 いと、シャフラノフシフトを考虑した，上り現実に近 い取扱いの二つの場合について，磁力線の貫通パター ンを求めた。磁気島の重なりて磁力線が統計化するこ とが確認されると同時に，ヘリカルコイル電流の強い 場合には，壁近傍で磁力線の壁へのつながり方に構造 性が現れることを指摘した。簡単化したもデルでは磁 力線の拡散過程が調へられた。この結果は, 磁力線の 振舞いは単純な妨散過程では表しきれないととを示し た。最終的モデルは，実験と対比する場合に適切であ ると考元る。

著者らは, トカマク平衡解の取入れ方について議論 していただいたテキサス大学オースチン校核虽合研究 センターDr. S. C. McCool と Dr. A. J.'Wootton に 感謝します。本研究は文部省科学研究費（核融合特別 研究, 課題番号 62050023) の援助を受けて行われた。 (昭和 63 年 4 月 11 日受付, 同 63 年 7 月 28 日再受付)

\section{文献}

(1) A. Samain, A. Grosman \& W. Feneberg: "An Ergodic Divertor for Tore Supra", J. Nucl. Mater, 111 \& 112, 408 (1982)

(2) J.S. deGrassie, N. Ohyabu, N.H. Brooks \& the TEXT Group: "Ergodic Magnetic Limiter Experiments on TEXT with 7/3 Resonance", J. Nucl. Mater., $128 \& 129,226$ (1984)

(3) N. Ohyabu, J.S. deGrassie, N. Brooks, I. Taylor, H. Ikezi \& the TEXT Group: "Ergodic Magnetic Layer Expriment", Nucl. Fusion, 25, 1684 (1985)

(4) A. J. Wootton, R. D. Bengston, J. A. Boedo, R. V. Bravenec, K.L. Empson, et al.: "Particle and Thermal Transport and Resonant Field Experiments in TEXT", Proc.. 11th Int. Conf. Plasma Phys. \& Controlled Nuel. Fusion Res. Kyoto, Japan, 1986 (International Atomic Energy Agency, Vienna, Austria, 1987), Vol, 1, p. 187

(5) S. Takamura, N. Ohnishi, H. Yamada \& T. Okuda: "Electric and Magnetic Structure of an Edge Plasma in a Tokamak with a Felical Magnetic Limiter", Phys. Fluids, 30, 144 (1987)

(6) S. Takamura, H. Yamada \& T. Okuda : "Control of Tokamak Edge Plasma by Static and Rotating Helical Magnetic Limiters", Nucl. Fusion, 28, 183 (1988)

（7）高村・大西・山田・奥田:「外部へリカル磁場化よるエルゴ

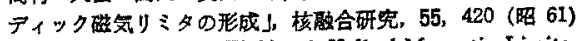

(8) W. Feneberg \& G. H Wolf: "A. Helical Magnetic Limiter for Boundary Layer Control in Large Tokamaks" "Nucl. Fusion, 21, 669 (1981)

(9) T.J. Martin \& J.B. Taylor: "Ergodic Behavior in a Magnetic Limitez", Plasma Phys. \& Controlled Fusion, 26. 321 (1984)

(10) X.Y. Yu \& J.S. deGrassie: "Mapping Techniques for the GA Ergodic Magnetic Limiter Experiment on TEXT". Report of Fusion Research Center, The University of Texas, FRC \#292 (1986)

(ii) S. Takamura, H. Yamada, S. C. McCool \& A. J. Wooton: "Computer Code for Field Line Tracing on TEXT Ergodic Magnetic Limiter", ibid., FRC 298 (1987)

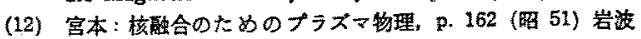
费沾

(13) A. B. Rechester \& M.N. Rosenbluth : "Electron Heat Transport in a Tokamak with Destroyed Magnetic Surfaces", Phys. Rev. Lett., 40, 38 (1978)

(14) T. H. Stix: "Plasina Transport across a Braided Magnetic Field", Nucl. Fusion, 18, 353 (1978\&

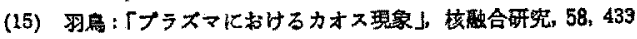
(晊 62)

（16）高安：フラタタル，p. 21 (昭 61) 朝拿書店 